\title{
Swami Vivekananda -The Thinker
}

\author{
Sudhish Chandra Banerjee* \\ 2 Diamond Park, Kohinoor Apt. Flat-10, PO-JOKA, Kolkata-700104, India
}

*Corresponding Author: Sudhish Chandra Banerjee, 2 Diamond Park, Kohinoor Apt. Flat-10, POJOKA, Kolkata-700104, India

Abstract: Swami Vivekananda's depth of thought on varied topics and wisdom on truth-seeking spirituality, impressed alike the intellectuals, scientists, scholars or common folks, whosoever met him, in both India and abroad. Swamiji's thoughts being beyond our comprehension, certain piecemeal ones are elucidated.

Some of his original ideas included:

- India's welfare lay in educating the masses with renaissance of its lost spirituality eliminating deceptive dogmas on caste prejudices (don't-touchisms).

- Divinity is innate in all which can be perceived practising the Yogas.

- Self-less work for others elevates the spirituality of the giver; though no progress is made with corresponding digression elsewhere.

- Narrated the features on alternate rule of intellect (Brahmin), military (Ksatriya), commerce (Vaisya) \& labour(Sudras)- reigning since ages.

He Forecasted:

- Next upheaval of Sudra rule to come from Russia \& China - proved true.

- Advised Indians fifty years before its independence (1897), to worship 'Mother India', as their only God for next 50 years.

- Attack of India from China apprehended after the British leaving India-proved true.

- $\quad$ That Europe was sitting on a volcano - proved true with two world wars that followed

Keywords: Caste concept, Cyclonic monk, Chicago parliament of religion, Innate divinity, Secret of work, Vedanta, Spirituality, Sankaracharya.

\section{INTRODUCTION}

Einstein said "I want to know how God created this world. I am not interested in this or that phenomenon, ......... I want to know His thoughts; the rest are details" ${ }^{\text {. }}$. But it is history that Einstein, the great scientist of the last millennium, though made quite a number of predictions on the piecemeal phenomenon of Nature, many of which (gravitational wave etc.) proved to be true even a century after Einstein's predictions (in general theory of relativity etc.); but his endeavour of knowing creator's thought remained elusive, despite his subsequent forty years pursuit to develop even just the unified field theory itself.

Likewise, it would always be beyond our realm to comprehend the thoughts of Swami Vivekananda. Such efforts can at best be considered as an attempt to grasp stray thoughts of Swamiji from his writings and lectures or from stories and anecdotes of the life of this dazzling personality, who is said to be the voice of Sree Ramakrishna -the prophet of the nuclear age.

A keen observer noted that "the fraction of the mind with which he attended to the world was brilliantly alert .... far more than a match for the keenest intellect. But .... far larger part lay quiet and untouched beneath the surface, always absorbed in God, (and always) ready to pour out blessings upon, and alter the lives of those who came to him. ....How often Swamiji verged upon Nirbikalpa 
Samadhi, (was) only to be drawn back by Sri Ramakrishna (in his resurrected appearance), or by his own love and compassion for man. ... He always lived on the border line between relative and the Absolute, as a prophet of his supreme eminence must" ${ }^{\prime 2}$. It has been reported that a great many people who came across Swamiji could find... 'in his presence not only solace of profound ...wisdom, but ...the friendship of one who was not divorced from an interest in life round him. He was (their) father, son, teacher, friend" .

After his charismatic success in Chicago Parliament of religion in 1893, Swamiji was honoured with accolades in the oft-sighted posters that appeared with inscription on Swamiji, as 'an orator by divine right', 'a perfect master of English language', 'sensations of the world's fair Parliament', and lovingly called the 'Cyclonic Monk', for his whirl-wind like lecture tours around'. Swamiji himself was however, quite dismissive of these extraordinary extroversive attributes showered upon him. He wrote to Mary Hale on $15^{\text {th }}$ March, 1894, "I will tell you what is to my taste; I cannot write and I cannot speak, but I can think deeply, and when I am heated, can speak fire, however to a very select few. $" 4$.

This invokes us to delve into such deep thoughts that Swamiji spoke of to be of his liking, which is more electrifying than even his inspiring speeches and powerful pen. This article is an attempt to highlight the nature and extent of some of his thoughts and visions, by which the society got influenced. It is of course beyond the capacity of this article to grasp all aspects of his thoughts as we get to know from the 9 volumes of his complete works.

The themes thus identified for illustrations are:

1. Swamiji's influence over the contemporary architects of the society as also the commoners.

2. Swamiji's novel thoughts for the benefit of humanity and their long term impact.

3. Swamiji's vision in predicting the future course of history.

Brief accounts on the above topics are discussed below, in order to grasp some of the thoughts of this great soul.

\section{SWAMIJI'S THOUGHTS INFLUENCING UPON THE SOCIETY}

Swamiji (then Narendranath) in his school days, "was encouraged by his father to meet notable scholars and discuss with them various intellectual topics usually considered too abstruse for his age" 5 . Later, in his college days Narendranath got so well conversant with western philosophical thoughts that he used to communicate with philosophers like Herbert Spencer even pointing out his reservations on certain points. Spencer agreed with Swamiji's observations to revise in subsequent edition of his book ${ }^{6}$. Fr. William Haste, the principal of his College had a very high impression of Narendranath and said that he didn't find such talented boy with original thinking even in German Universities ${ }^{6}$.

After Swamiji's Guru-Sree Ramakrishna passed away, Swamiji with his fellow disciples led an austere monastic life of extreme hardship at Baranagar Math. This was a rented dilapidated house with poisonous snakes all around. For months they sustained on boiled rice, salt and bitter herbs and when they had no food at all, which occurred very often, they spent day and night in prayer \& meditation ${ }^{7}$. Swamiji during this period took the lead of preparing his brother disciples in broadening their outlook from discussions and study of not only the scriptures and of holy books; but 'assimilating the thought- currents of the world of various systems of philosophy, history \& literature and of course focussed with God realization as the central theme'?

In the next phase Swamiji traversed throughout the length and breadth of India, moving as a roving monk to rekindle the lost spirituality of India intermingling with people of all sorts. Moving penniless, today he may be the guest of honour in the palace of the Maharaja of a princely state, or the honoured guest of a noble man of the city; tomorrow may be found literally with no shelter and depending on the meagre alms of a pariah staying in a thatched hut or; just under a tree with no food or shelter.

But one thing was common at every place that Swamiji visited or, stayed. As nectar attracts honey bees, similarly people of varied backgrounds both rich and poor, scholars or students, the religious 
aspirants or proud agnostics, the noblemen or their subjects and persons of other faiths like Islam - all of them virtually thronged around him, keeping him busy with discourses day and night. Swamiji responded tirelessly over their incessant queries and quests on knowledge of all sorts. Swamiji was ever ready and willing to enlighten them with his eloquence and vast knowledge of both western and eastern thoughts. He was equally at ease whether discussing 'Spencer or Sankaracharya, Shakespeare or Kalidasa, Darwin or Patanjali, Jewish history or Aryan Civilization, ${ }^{8}$. He took command over the crowd around him whosoever is and wherever it be, becoming a celebrity overnight, as soon as he started to talk with his majestic personality and/or, sing (devotional songs) with his sonorous enchanting voice.

Many of them were so much influenced from the spirituality and wisdom of Swamiji, that they took initiation from him and became his lifelong devotee to serve his mission. To name a few of them, amongst many others are the Maharajas of Khetri/ Limri/ Mysore/ Ramnad and their noblemen, or common folks*.

[*Mr Alsinga Perumalt--an atheist science teacher came to challenge Swamiji, But later on became His great devotee. Swamiji, affectionately called him Kidi, citing of Caesar's saying, Veni, Vidi, Vici- I came, saw and conquered; thus kidi got conquered in no time In fact, Caesar's quote could be said to be applicable for all those whosoever met Swamiji].

Maharaja Mongal Singh of Alwar got rid of his high-browed notion that the Hindus worship stones and mud and learnt from practical demonstration by Swamiji, that they do not worship the stone/mud, but the emblem of God in the stone/mud built images, etc. He later on became a great admirer seeking for the company of Swamiji with great reverence to him $^{12}$.

In addition to his scholastic accolades some others, on listening his heart rending devotional songs and enchanting spiritual discourses (as in Alwar, etc. ) followed him like the pied piper of Hamelin. Some others were moved seeing in him the harmony of eastern spirituality with western science, and also feeling in him from their heart of hearts an authority in spiritual excellence; like the Maharaja of Khetri, or Forest officer Haripada Mitra (and his wife), etc. who accepted \& regarded him as their Guru. In fact, Swamiji had quite a high impression of Ajit Singh, the Maharaja of Khetri. He knew that high ideals can be percolated to the people at large, if their rulers \& makers of the society are imbibed with virtue and values of life. It is said that the Maharaja of Khetri even took lessons of Physics, Chemistry \& Astronomy from Swamiji, his Guru (in addition to spiritual lessons), who also set up a laboratory at the top floor of his palace ${ }^{13}$.

It may be relevant to add here of an amazing feat of Swamiji as to reading books by just glancing at the pages to memorise the whole content of it. On being asked by Maharaja Ajit Singh as to how he could read so fast, Swamiji replied, 'When a kid learns to read, he pronounces every letter to read. Later he can read just glancing at the words; on further maturity he glances at the sentence to grasp its meaning at once. With absolute celibacy and practice of concentration, one can understand the whole page itself at a glance. Anybody with such practice can achieve this acumen ${ }^{14}$.

Many of the scholars and intellectuals were amazed at the brilliance and sharp wit of this young monk, and prophesied that Swamiji is sure to come up as a world famous person. The list of such persons is quite long ${ }^{15,16,17}$. One of such admirers Sankar Pandurang, a great Sanskrit scholar took the help of Swamiji in translating Atharba Vedas, which he was doing then ${ }^{18}$. He considered Swamiji to be the right person to hold high the flag of Vedanta and of the conscience of India with its glory, at the world parliament and suggested Swamiji to go to Chicago for the job.

The voice urging Swamiji to go to Chicago as the representative of Hinduism was becoming louder and louder, and with the support of Maharajas \& the noblemen the money needed for the same was being gathered. It may be of interest to note that even the Muslim ruler of Hyderabad, Nawab Sir Khursid Ja was so impressed talking with Swamiji that he also wanted to make lavish contribution for this cause ${ }^{19}$. But Swamiji fully depending on providence was not ready to accept it then, and the entire money collected was distributed for the service of the poor ${ }^{20}$. Later on becoming sure of such journey to be of God's will, on getting the affirmation letter from Sree Ma (Sree Sree Sarada Devi), Swamiji agreed to set sail for Chicago, with funds raised mainly from the common people. His disciples from Madras with the leadership of Alasingha Perumal, virtually begged from door to door 
to collect the required fund, ${ }^{21}$ and were also helped by the Maharajas like, Ajit Singh of Khetri, and others as well.

It may not be out of place to mention here that Swamiji was held in high esteem by Muslims as well, whose hospitality he accepted many a times. When Munsi Jagmahan Lal, the private secretary of Maharaja of Khetri discovered Swamiji, he was then staying as the honoured guest of a Muslim advocate near Mount $\mathrm{Abu}^{22}$. Swamiji mentioned of a Muslim Fakir at Allahabad, whose features suggested that he attained the illumined state (a Paramhansa) ${ }^{23}$. Swamiji along with Hindu \& Jain pilgrimages visited a number of Muslim shrines and was all praise for the Mughal artefacts, as well. 24

Thus we find this penniless young monk virtually deluged entire India with his elevated divine thoughts, and won over the minds of the people cutting across social status or, religious faith. He won over them with his open mind and liberal outlook, a pure and austere life, a burning patriotism with love and sympathy for all; besides his attainment of God-like omniscient wisdom. It may be relevant to add here that Swamiji's wisdom with magnetic personality winning over the people of all walks of life, was not bound within India but virtually encompassed round the globe, wherever he kept his footprints on. A few such incidents worth citing are narrated below.

The first one occurred on way to Chicago when Swamiji, after getting down at Honkong reached Canton to visit the famous Chinese temples with his German co-passengers of the ship. Though their translator discouraged it to be unsafe nearing the temple, but Swamiji insisted upon visiting there. As they approached the temple, they found a few angry people rushing towards them with sticks in hand and all started fleeing except Swamiji. Laughingly Swamji stopping the translator asked him to tell the Chinese translation of the word 'Yogi', to which Swamiji spoke aloud at them, saying 'he was an Indian Yogi'. It worked like a magic. They all then prostrated before Swamiji, took him inside the temple as an honoured guest and showed him their holy books and of the temple. Swamiji was amazed to find their text written in Sanskrit using the old Bengali script, suggesting the influence of Indian thoughts influencing upon China in olden times ${ }^{25}$ This particular incident, of not running away but declaring him an Indian Yogi and thereby earning great regards from those angry priests of the temple, speaks volumes not only of Swamiji's wisdom, but also of his conviction and firm faith on mutual respect of the two old civilisation of China \& India.

Then on reaching US and after overcoming many a hurdle and hardship, Swamiji was at last introduced to be the guest of one John B Lyons, at his Michigan Avenue House, brought at midnight by Henry Burrows. It was already packed with Chicago delegates and personal guests of Lyons, many of whom were southerners, who were not at all comfortable with the natives. In the morning Mrs Lyons becoming apprehensive of their southerner guests' concerns spoke of it to Mr Lyons and were planning to shift Swamiji to some hotel. Mrs Lyon's granddaughter Miss Conger writes in her memoirs, "My grandfather half hour before breakfast went to the library. There he met Swamiji and before breakfast was served he came to my grandmother and said, 'I don't care a bit Emily if all my guests leave! This Indian is the most brilliant and interesting man, who has ever been in our home and he shall stay as long as he shall wish.",26

Miss Cornelia Congers memoirs gives another account of Swamiji's encounter with the intellectual friends of her aunt Catherine who invited a host of them to meet Swamiji, who said that modern scientists and psychologists can 'show up' Swamiji's religious beliefs in no time. But they found 'Swamiji's great knowledge on Bible, Koran, as well as various Oriental religion. His grasp of science and of psychology were astounding. Before the evening was over the 'doubting Thomases' threw up their hands and admitted that Swamiji had held his own on every point and they parted from him with warmest admiration and great affection. ${ }^{27}$

Famous scientists like Lord Kelvin, Professor Von. Helmholtz as well as agnostic orator like, Robert Ingersoll, had also the privilege of meeting Swamiji, as invited guests in vegetarian dinner developing mutual regard with each other, from their discussions on secular topics ${ }^{27}$.

Martha Brown Fincke writes in her reminiscence on Swamiji's wordy duels with a host of well versed European scholars, thus, "...to our house came the college president (Smith college, USA), the 
Head of Philosophy dept. and several other Professors, the minister of Northampton churches and a well known author. ......The conversation ... dealt mainly with Christianity and why it was the only true religion. .....One felt that he (Swamiji) was being challenged. Surely these leaders of thought ....had an unfair advantage. They knew their Bibles thoroughly and the European system of Philosophy.....(but) the surprising result that followed cannot be exaggerated with intensity. To texts from Bible the Swami replied by other and more opposite ones from the same book. In upholding his side of argument he quoted English philosophers and writers on religious subjects. Even the poets he seemed thoroughly........quoting Wordsworth \& Thomas Grey. ....I exult in the air of freedom that blew through the room as he broadened the scope of religion till it embraced all mankind. ....I felt triumphant with him. ......they felt it was thumps down for them. .....A Swami of Belur Math said, Swami Vivekananda personified Love. To me that night he personified Power", ${ }^{28}$.

No wonder that Prof. John Henry Wright, the noted Prof. at Harvard University, recommended Swamiji to the (Chicago ) Parliament authorities with the note, "He is more learned than all our learned professors put together." ${ }^{29}$ And what followed at Chicago Parliament was a history unfurling a new era of unifying liberal thoughts, introduced by Swamiji. "Both Mr Barrows (convenor of the Parliament) and Houghton commented "when Mr Vivekananda addressed the audience as 'Sisters \& Brothers of America', there arose a peal of applause that lasted for several minutes. .....The audience of Parliament, as a whole, could not have known precisely why it cheered for Swamiji at his first words.....Was it not rather, inspired by something unspoken that came through Swamiji's words?......thence forth he was the star of the Parliment" ${ }^{30}$. It was thence reported in Boston Transcript, "the four thousand fanning people in the Hall of Columbus would sit smiling and expectant, waiting for an hour or two of other man's speeches, to listen to Vivekananda for fifteen minutes." ${ }^{31}$.

The overall influence of Swamiji's speeches may be understood from Lucy Monroe report on closing session of Chicago Parliament. She wrote on Oct.7, 1893, "The impertinence of sending half educated theological students to instruct the wise and erudite Orientals was never brought home to an English speaking audience so forcibly" ${ }^{32}$. Sir Hiram wrote, "...here was a specimen .... who knew more of philosophy and religion than all the parsons and missionaries in the whole country......Shall we waste our money in sending the missionaries who know nothing of religion as compared to this man (Swamiji), to teach such a man as he. No!" 33 "And the missionary income fell off more than a million dollar a year as a consequence.", ${ }^{, 33}$.

Naturally Swamiji had to face slandering campaign from such missionaries (and also of some of his jealous countrymen), which however were outweighed from the huge American admirers; of which Sir Hiram wrote, "When however Vivekananda spoke, they saw they had a Napoleon to deal with...Vivekananda became a Lion of the day" ${ }^{33}$. Swamiji however, was not against sending missionaries to India; he wanted them to stop defaming India. He said, "Send missionaries to them (Indian) to teach them how to earn a piece of bread, and not to teach them metaphysical nonsense"

At the Paris Congress of religion, held after Chicago, Mr Gustav Oppert a German Pandit read a paper on the significance of Shalograma Shila \& of Siva Linga, considered holy \& worshipped by the Hindus. According to him "the Shiva -Linga is the phallic emblem of the male and the Shalagram to be of the female generative principle - both are but the component parts of Yoni ${ }^{, 35}$ ! Swamiji repudiated such clumsy views and said that " the worship of Shiva Linga originated from the famous hymns of Atharva Veda Samhita, sung in praise of Yupa Stambha, the sacrificial alter post. ....It is said in the hymn that the said Stambha or Skambha is put in place of eternal Brahma.....Yupa Skambha gave place in time to Shiva-Linga, and was deified as the highest Devahood of Shri Sankara. ....'(On the other side) The Shalagram -Shilas are natural stones -case of the Buddhist Dhatu -Garbha, and ... being worshipped by the other forms of Buddhists, gradually got into Vaishnavisms" ${ }^{35}$. These scholastic observations of Swamiji, should make Orientals to become conscious of not imitating the clumsy logic of half-baked Sanskrit Pandits of the West, to get to know of their own scriptures \& culture.

If we analyse the talks of Swamiji, we would find that though he went at Chicago Parliament to speak on Hinduism, but it turned out, as if he took the brief for all the religions of the globe, to introduce the spirituality aspects in all of them. He boldly asserts that all religions seeks for the 
attainment of the same Truth, and the Hindus not only tolerates all religions, but accepts them all to be leading to the same goal. It was as though the soul of America had long asked for spiritual sustenance and had now been answered", 3 .He said, "The Christian is not to become a Hindu or Buddhist, nor Hindu or a Buddhist to become a Christian. But each must assimilate the others and yet preserve its individuality and grow according to its own law of growth, ${ }^{, 36}$.

Speaking specifically over Vedanta, Swamiji wrote to Alsinga on $6^{\text {th }}$ May, 1895, "All religion is contained in Vedanta......Vedanta applied to the various ethnic customs and a creed of India is Hinduism. The first stage i.e. Dvaita applied to the ethnic ideas of Europe is Christianity; as applied to the Semitic group, Mohammedanism. The Advaita as applied to the Yoga perception is Buddhism etc. .....You will find that although the philosophy is the same, the Shaktas, Shaivas, etc. apply it each to their special cult and forms" ${ }^{37}$. This observation of Swamiji speaks volumes of his analytical mind making close examination on the genesis of all the religions, as could be ascertained from the perspective of Vedanta. The present subject on comparative religion may be said to have emerged from such introspective thoughts of Swamiji.

In reply to a query at Boston, Swamiji said "The Vedantic spirit of religious liberality has very much affected Mohammedanism, 38 . He wrote to Sarfaraj Khan, a devotee of Swamiji, "My experience is that if ever any religion apply this equality (of Vedanta) in an appreciable manner, it is Islam and Islam alone. .....without the help of practical Islam, theories of Vedantism, however fine and wonderful they may be, are entirely valueless to mankind ${ }^{39}$. At Chicago Parliament on $26^{\text {th }}$ Sept. 1893, speaking on Buddhism, Swamiji said, "Sakyamuni (Buddha) himself was a monk.......he had the large heartedness to bring out the truths from the hidden Vedas and throw them broadcast all over the world" ${ }^{40}$.He said further, "Buddhism cannot stand without the brain and philosophy of Brahmins (Vedanta), nor the Brahmin (Vedanta) without the heart of the Buddhist. ....This separation between the Buddhist and Brahmin (Vedanta) is the cause of down fall of India" ${ }^{, 47}$. Such novel observations of Swamiji are not only original approach speaking volumes of his wisdom on religious principles, but are quite thought provoking for a closer study of history.

We thus find that Swamiji's wisdom and richness of thoughts with purity of mind (spirituality) not only won over the Indian mind, but made rather a greater impact on the Western nations like America and UK. For the first time the western world learnt to become respectful of the eastern culture and philosophy. Swamiji's speeches writings and thoughts influenced many men and women of America and UK to sacrifice their whole life to become his ardent follower and devotee. A number of Vedanta centres opened up in both these countries and are functioning even 115 years after his death with ever increasing enthusiasm.

In addition to making a stir globally, some of the thoughts of Swamiji that might be considered to have lasting impact in shaping up the society, are being taken up for study.

\section{A Few Novel Thoughts of Swamiji}

The particular topics, as are considered relevant for necessary discussions, are as below.

- Welfare of the Indian masses.

- The caste concept as prevailing in India, with its different dimensions.

- The secret of work and of the duty.

- The concept on the innate divinity of man and scope of its blooming.

A brief account of them, elucidating Swamiji's thoughts with his concerns and views on them, are highlighted below.

\subsection{Welfare for the Indian Masses}

Swamiji confided to his disciple Swami Sadanada that his Guru- Sree Ramakrishna has entrusted him with a mission to uplift the (then) degenerated India, but he was yet to find the way out ${ }^{9}$. He had wandered about penniless throughout the length and breadth of India, intermingled with people of all walks of life and was sad to see the plight of the hungry millions. He felt deeply for the poor and downtrodden of the then India under British rule. With turmoil of heart Swamiji reached Cape Comorin and prostrated before the virgin Goddess Kanyakumari and worshipping her wanted to 
meditate and think deeply on the solution to uplift the degenerated masses. He then swam across the roaring waves of the Indian ocean to meditate on the rock at the southernmost tip of India. He had the roaring waves of Palk Strait looking at the landmass of Himalayas to Cape Comorin in his front, Bay of Bengal in the right, Arabian Sea in the left and the Indian Ocean at his back.

He meditated the whole night over the whole of India- "it's past, present and future, her centuries of greatness and also her centuries of degradation. He saw that it was not the religion that was the cause of her downfall, but on the contrary, the fact that her true religion, the very life and breath of her individuality, was scarcely to be found, and he realised that her only hope was renaissance of the lost spiritual culture of the ancient Rishis" ${ }^{, 42}$.

It clearly revealed to him that contrary to the foreign critics and their Indian imitators the downfall of India has been caused because of the falsehood, superstition and hypocrisy that were practised in the name of religion ${ }^{43}$. Feeling deeply on such points Swamiji later wrote to Swami Ramakrishnananda, "Do you think our religion (as is practised now) is worth the name? Ours is only Don't- touchism, 'touch me not'.........A country where millions of people live on flowers of the Mahua plant - and a million or two Sadhus and a hundred million or so Brahmin suck the blood of these poor people .....is that a country or hell? Is that a religion, or devils dance?" 44 . He wrote in the same letter of giving them right 'education' for their upliftment may be handing over teaching material at their door and to give back the nation its lost individuality. He wrote, "We as a nation have lost our individuality; we have to give back the nation its lost individuality and raise the masses"

On this question of imparting education as the solution, Swamiji wrote on another occasion, "The chief cause of India's ruin has been the monopolising the whole education......among a handful of men. .....if we are to rise again we have to do it ...by spreading education among masses.............Through education comes faith in one's self, and through faith in one's self the inherent Brahman wakes up in them." 45 .

Swamiji speaking on 'The Future of India', reminded saying, "This is the ancient land where wisdom made home before it reached any other country.......This is the land where Aryan, the Dravidian, the Tartar, the Mogul, the European - all nations of the world, as it were, pouring their blood into this land. ......of manners and customs there is more difference between two Indian races than between the European and Eastern races. The one common ground we have is our sacred tradition, our religion. In Europe, political ideas form the national unity. In Asia, religious ideals form the national unity. ...to the Indian mind there is nothing higher than religious ideals. ....work in any other line without first strengthening this would be disastrous. ...Our life blood is spirituality" ${ }^{\prime \prime 6}$.

It may be relevant to add that Swamiji did not mention spirituality of the Hindus only. He meant spirituality to be of importance of the whole of Indian masses, irrespective of their faith. He wrote in a letter, "I see in my mind's eye the future perfect India rising out of this chaos and strife, glorious and invincible, with Vedanta brain and Islam body. For our own motherland a junction of the two great systems, Hinduism and Islam - Vedanta brain and Islam body - is the only hope" ${ }^{39}$.

Swamiji had high impression on the virtues of the poorer masses than their counterparts in Europe, and said, "In India my experience is that poorer the man and better he is in the point of morality ",48. He further said, "Let new India arise - out of the peasants' cottage, grasping the plough; out of the huts of the fisherman, the cobbler, and the sweeper. Let her spring from the grocer's shop, from beside the oven of the fritter-seller. Let her emanate from the factory, from marts, and from markets. Let her emerge from groves and forests, from hills and mountains" ${ }^{49}$.

Like a great Patriot, Swamiji gave an inspiring clarion call to all the Indians particularly the educated elites, "Oh India ! ....forget not that the lower classes, the ignorant, the poor, the illiterate, the cobbler, the sweeper, are thy flesh and blood, thy brothers. ....proudly proclaim, 'I am an Indian, every Indian is my brother....... Oh Thou mother of strength, take away my weakness, take away my unmanliness, make me a Man!',50.

\subsection{Caste Concept as Prevailing in India}

As mentioned before, Swamiji was very much against the untouchability and gave a clarion call to the higher caste to consider the lower castes as their brother, their flesh and blood ${ }^{50}$; but at the same time 
he had a pragmatic view of the caste system and considered it to be just a social system and had nothing to do with religion. He asserted, "Beginning from Buddha to down to Ram Mohan Roy, everyone made the mistake of holding caste to be a religious institution and tried to pull down religion and caste altogether, and failed. But in spite of all the ravings of the priests, caste is simply a crystallised social institution, which after doing its service is now filling the atmosphere of India, with its stench, and it can only be removed by giving back the people their lost individuality. Every man born here in America knows that he is a man. Every man born in India knows that he is a slave to society" ${ }^{51}$.

He categorically questioned Pramadadas Mitra, a great Sanskrit Scholar in a letter on $7^{\text {th }}$ Aug.1889, "The Doctrine of caste in the Purusa-Sukta of the Vedas does not make it hereditary - so what are those instances as the Vedas where caste has been made a matter of hereditary transmission ? .........Why should the Shudra not study Upanishad?" "52. His pain for the system prevailing, was expressed in a subsequent letter on $11^{\text {th }}$ Aug.1889, "I have no doubt that according to the ancient view in this country, caste became hereditary, it cannot also be doubted that sometimes the Shudras used to be oppressed more than the helots among the Spartans and Negroes among the Americans (during Swamiji's time in nineteenth century, not now). .....I know it is a social law. ...It also means grave harm if one is bent on going beyond Guna \& Karma and cherishes in mind any caste distinctions" ${ }^{\prime 53}$.

But at the same time, Swamiji speaks as a pragmatic thinker, "I have seen castes in almost every country in the world, but nowhere is their plan as glorious as here. If caste is thus unavoidable, I would rather have a caste of purity and culture and self sacrifice, than a caste of dollars. ........Carry the light and the life of Vedanta to every door, and roue up the divinity that is hidden in every soul ${ }^{54}$. But he did not advocate hereditary caste system.

In a talk at Oakland on $19^{\text {th }}$ March, 1900, he stressed upon saying, "The worst failure of caste (hereditary) is that it suppresses competition, and checking of competition has really been the cause of the downfall of India and its subsequent conquest by foreign races" ${ }^{\prime 55}$. In trying to get to this ill of the present society, Swamiji says "..... in the beginning of the Satya Yuga there was one caste the Brahmins, and then by difference of occupation they went on dividing themselves into different castes .........And in the coming Satya Yuga all the other castes will have to go back to the same condition $^{56}$.

He adds, "The solution is not by bringing down the higher, but by raising the lower up to the level of the higher. ...whole work is to raise the Chandala up to the level of Brahmin" ${ }^{, 57}$. Here Swamiji advocates upon popularising and spreading the learning of Sanskrit language, citing it to be anonymous to our culture and commenting 'Sanskrit \& prestige go together, ${ }^{57}$.

It may be relevant here to cite Swamiji's letter to one his fellow monk-- Sashi, where he wrote with great reverence for his Guru (Sree Ramakrishna). He wrote from USA in 1895, saying, “ ... From the date He (Sree Ramakrishna) was born, has sprang the Satya Yuga (golden Age). Henceforth ...the distinction between men and women, rich and poor, ...Brahmins and Chandalas - he lived to root out all. ...He was the harbinger of Peace - the separation between Hindus and Muslims, between Hindus and Christians; all are now thing of the past. In this Satya Yuga the tidal wave of Sree Ramakrishna's Love has unified all ${ }^{158}$. Somewhere else Swamiji said, with the advancement of science, the work of the Sudras would be done by machines. Both these prophecies of Swamiji- the loosened hereditary caste distinction, with scope of all to be raised, as well as on scope of most Sudra work being done by machines- seem to give some ray of light in resolving the age old ills of caste related hatred and discrimination.

\subsection{The Secret of Work \& of Duty}

We are all familiar with the term 'work is worship' and also of an ideal on 'our duty to be of 'helping others' and 'doing good to the world'. But Swamiji, refutes all these which seem to be an apparent anomaly. Particularly because Swamiji himself said in the same write up,

"Inactivity should be avoided by all means. Activity always means resistance. Resist all evils, mental and physical; and when you have succeeded in resisting, then will calmness come, ${ }^{, 59}$. 
Swamiji, who could gauge all types and aspects of work in its entirety, could be bold enough to comment, "All work in the world is composed of good and evil. We cannot do any work which will not do some good somewhere; and there cannot be any work which will not cause some harm somewhere" ${ }^{60}$. Swamiji gave a pertinent example also to prove his point. We have to think deep and analyse within ourselves to realise this hard truth which is universal.

He asserts more clearly "there is no action which does not bear good and evil fruits at the same time. ......however we try there cannot be any action which is perfectly pure, or which is perfectly impure, taking purity and impurity in the sense of injury and non-injury.........good and evil are the obverse and reverse of the same coin" ${ }^{61}$.That this pragmatic statement is a hard reality, is learnt from experience- both in individual life as well as in historical events.

Swamiji wrote to Goodwin on 8th Aug. 1896, “ ... Never be deluded with tall talks as you hear in America, about 'human progress' and such stuff.. There is no progress without corresponding digression. ....In middle ages there were more robbers, now more cheats. At one period there is less idea of married life; at another, more prostitution. In one, more physical agony; in another thousand fold more mental. .....Are you happier than the red Indians. ?",62. These introspective thoughts of Swamiji should invite serious examination by researchers of history and sociology and nations should strive to increase their happiness index rather than the varied economic indices.

It also invokes us to ponder over the question, then why should we work or do our duty, if it is virtually futile? To this query, Swamiji replies very significantly and said that we should work, "apparently to help the world, but really to help ourselves. ....is it not a blasphemy that the world needs our help? ...to go out and help others..is the best thing we can do, although in the long run, we shall find that helping others is only helping ourselves. ... The only help is that we get moral exercise. This world is neither good nor evil; each man manufactures a world for himself. ...It is not the receiver that is blessed, but it is the giver. ...All good acts tend to make us pure and perfect. ......we must work and constantly to do good, because it is a blessing to ourselves. .... (Though)The world will go on with its happiness and misery through eternity. ....this world is like a dog's curly tail and will never get straightened .......you need not worry or make yourself sleepless about the world; it will go on without you. When you avoid fanaticism, then alone will you work well. ...the calm man, of good judgment ....of great sympathy and love, does good work and so does good to himself. ....It is a great privilege for all of us to be allowed to do anything for the world. In helping the world we really help ourselves" 63 . Swamiji continues, "When you are doing any work, do not think of anything beyond. Do it as the highest worship and devote your whole life to it for the time being....to the unattached worker all duties are equally good, ${ }^{\prime, 63}$.

Swamiji's keen introspection throws light on not only of the rationality of doing good work, but on our thoughts also. Our thoughts are also a type of work though potent; it is from our thoughts only that breeds work as the result. Swamiji, the Yogi, cautions us saying, "When I am doing a certain action; my mind may be said to be in certain state of vibration; all minds which are in similar circumstances will have the tendency to be affected by my mind. .....This influence of thought on mind will vary according to distance and other causes. ..Suppose I am doing an evil act ....all minds in the universe, which are in a similar state have the possibility of being affected by vibrations of my mind. ......when I am doing good action, all minds similarly strung have the possibility of being affected by my mind" 64 .

Yogic science says, "Every thought projected from every brain goes on pulsating ...until it meets a fit object that will receive it. ...that is why an evil doer ...goes on doing more and more evil. ...with doer of good ..will open himself to all good waves that are in the atmosphere, and his good actions also will become intensified. .....like all other forces in man, these good and evil also gather strength from outside. ....the action that one has done cannot be destroyed until it has borne fruit; no power in nature can stop it from yielding result', ${ }^{65}$

Swamiji concludes saying, " The main effect of work done for others is to purify ourselves. ...Man thinks foolishly that he can make himself happy, and after years of struggle finds out at last that true happiness consists in killing selfishness. ....Here we find that Jnan, Bhakti and Karma-all come in one point. The highest ideal is eternal and entire self abnegation" ${ }^{66}$. 
Sister Nivedita, the spiritual daughter of Swamiji, opines on Swamiji's view of work for attaining godliness and writes, "To him, the workshop, the study, the farmyard, and the field are as true and fit scenes for the meeting of God with man as the cell of the monk or door of the temple. To him there is no difference between service of man and worship of God ...between true righteousness and spirituality ${ }^{, 67}$.

\subsection{Innate Divinity of Man \& Scope of its Blooming}

It made quite a stir on $19^{\text {th }}$ Sept. 1893, at Chicago Parliament, when Swamiji quoting Vedic sages proclaimed, "Hear, Ye children of immortal bliss! Even ye that reside in higher spheres! I have found the Ancient One, who is beyond all darkness, all delusions: knowing him alone you shall be saved from death over again." ${ }^{68}$. Swamiji continued, "Ye divinities on earth -sinners? It is a sin to call a man so; it is standing libel on human nature." 68 .

As regards the innate spirituality potent in everybody without exception, Swamiji said, "God is in every man, whether he knows it or not" ${ }^{\prime}$. To stress upon it he said 'Every sinner has a future, whereas every saint has a past.' He added his mission to be of 'man-making', which means blooming of this spirituality within. The more we think of ourselves to be separate from the Whole the more miserable we become. So "Advaita is the basis of ethics ${ }^{70}$.

Swamiji gave elaborate lessons on Karma Yoga, Raja Yoga, Bhakti Yoga and Jnan Yoga for blooming of this innate divinity within us. In fact, Swamiji was the first propounder of this term Yoga in modern India; but is usually used today only for the improvement of physical body, the purpose of which however is mainly for the awakening of the innate spirituality.

In brief the 4 Yogas for such blooming of spirituality may be defined, as below:

Karma Yoga (Work) - The manner in which a man realises his own divinity through work.

Bhakti Yoga (Divine love) - The realisation of the divinity through devotion to, and love, of a personal God.

Raj Yoga (Meditation) - The realisation of the divinity through the control of mind.

Jnana Yoga (Reasons) - Realisation of man's own divinity through knowledge ${ }^{71}$.

Swamiji wrote to his UK disciple E.T. Sturdy on $11^{\text {th }}$ Feb, 1896 about these four Yogas, saying, "I want to give them (entire humanity) dry hard reasons (Jnan Yoga), softened to the syrup of love (Bhakti Yoga), and made spicy with intense work (Karma Yoga) and cooked in the kitchen of Yoga (Raj Yoga), so that a baby can easily digest it, ${ }^{, 72}$.

As regards Karma Yoga, Swamiji advocates for unselfish work with self abnegation to be of help in blooming our innate spirituality. And like a universal Guru, Swamiji assures us saying, “....in the first years, we shall find that our motives (to work) are always selfish; but gradually this selfishness will melt by persistence, till at last come the time when we shall be able to do unselfish work. .....there will come a time when we shall become perfectly unselfish; and the moment we attain that, all our powers will be concentrated, and the knowledge which is ours will manifest". ${ }^{73}$

It may be not be out of place to cite the noted Beatle singer George Harrison's (1943-2001) source of inspiration over his famous song, "My Sweet Lord". He admitted that he got inspired from Swamiji's quote, 'If there is God, we must see him. If there is a soul, we must perceive it ${ }^{\text {"74 }}$.

As regards the utility of the need of such man-making job or, the need of blooming of divinity of people in the society, it is considered very much relevant in today's context, may be citing the quotes of Swamiji, who said very rightly, "No nation is great or good, because Parliament enacts this or that law, but because its men are great and good"75. ..."So long as the society tries to cure evil by laws and institutions, evil will not be cured. The world has tried this method ineffectually thousands of years. Force against force never cures, and the only cure for evil is unselfishness" ${ }^{76}$. We need now more of such people in the society; we need people to obey the laws rather than make more laws.

\section{FORETELLING FUTURE COURSE OF HISTORY}

Mendeleev while developing the scheme of his periodic table predicted future discovery of certain elements, even stating their appropriate positions in the periodic table, subsequently proved to be true 
quite a number of decades later. This was possible because the scientist concerned had complete mastery over his scheme of the periodic table having thorough knowledge in Chemistry. Likewise Swamiji made quite a number of such forecasts of historical events, which speak more of the depth and excellence of his thoughts with complete mastery \& thorough knowledge over human history \& society, than trying to explain with the irrational logic of mystic Yogic power. A few such predictions made by Swamiji are stated below; some of which were of generalised type \& some very specific. They are as below:

I) Analysing the generalised course of history, Swamiji wrote to Mary on $1^{\text {st }}$ Nov, 1896, "Human society is in turn governed by four castes- the priests, the soldiers, the traders, and the labourers. Each state has its glory as well as defects. When the priest (Brahmin) rules, there is tremendous exclusiveness on hereditary grounds; ....none but they have any knowledge- none but them have the right to impart knowledge. Its glory is that at this period is laid the foundation of sciences. The priests cultivate the mind, for through the mind they govern.

The military (Ksatriya) rule is tyrannical and cruel, but they are not exclusive and during that period art and social culture attain their height.

The commercial rule comes next. It is awful in silent crushing and blood sucking power. Its advantage is, as the trader himself goes everywhere, he is a good disseminator of ideas collected during two previous states. They are still less exclusive than the military but culture begins to decay.

Last will come labourers (Shudra ) rule. Its advantage will be the distribution of physical comforts -its disadvantages (perhaps) lowering of culture. There will be a great distribution of ordinary education, but extraordinary geniuses will be less and less" 77.

Perhaps we are now facing that Sudra period and we find how true Swamiji's prophesies were, forecast more than a century back!

II) But the most baffling prophecy that Swamiji made was over Russia and China taking over command of this Sudra period. Christine in her reminiscences reported Swamiji to be saying, "The next great upheaval which is to bring about a new epoch will come from Russia or China". He said, "It would be Russia which he expects to lead the world next"; though at the end of nineteenth century in Swamiji's time, neither Russia nor China was in a position to dominate the world power78.

III) Strangely, in his address in 1897 (50 years before independence of India in 1947) Swamiji said like a national leader \& patriot, "For the next fifty years ....let all other vain Gods disappear for the time being. This (Mother India) is the only God that is awake, our own race- ...all other Gods are sleeping''79.

IV) He also made the prophecy that 'When the British should leave India, there would be a great danger of India being conquered by China78. Swamiji's foresight on these points were startling indeed; he being proved right in 1962 proving his prophecy to be true more than half a century later.

V) Swamiji also predicted after his trip to Europe that 'Europe was sitting on a volcano \& it might explode any time' 80 . It is now history that quite a few decades after this prophecy entire globe was rocked with two world wars ( 1914-1918, 1939-1945), which started from Europe.

VI) His other prophecy that, India will become independent through a unique and novel way, unprecedented in history' 80 ; also proved right. India's independence was a by product of the Second World War and indeed a novel one in the entire history of independence movements we know of.

All these forecasts speak volumes of unfathomable depth of thought process of Swamiji and of his grasp over human history \& of the society.

\section{CONCLUSiON}

This write up is thus like a child's attempt to catch the moon up above the sky, as reflected in a water bowl within his reach; Swamiji -the Thinker remains beyond our comprehension.

Just like common adage which says that one has to be Jesus to understand Him. Similarly; it is only another Vivekananda who can only make an account of His thoughts and lay claim to appraise on Swami Vivekananda -the Thinker. This write up is a modest attempt to understand some of the 
piecemeal thoughts of Swamiji, which lacks in expressing both the extensity and intensity character of his thoughts.

\section{ACKNOWLEDGMENT}

The author acknowledges his thanks to Dr Jayasis Bandyopadhyay, FRCOpth (Lond.), Consultant of James Cook University Hospital, UK, for overseeing the article and for his valuable suggestions.

\section{REFERENCES}

[1] In. < https://www.aip.org/history/exhibits/einstein/inbrief.htm> [18.05.2016]

[2] Marie Louis Burke (1994). Swami Vivakananda in the West, New Discoveries. The Prophetic Mission, Advaita Ashram, Kolkata, Part 1, pp- 178-179.

[3] Ibid. p.209.

[4] Letters of Swami Vivekananda (2012), Advaita Ashram, Kolkata, .dt. 15 ${ }^{\text {th }}$ March, 1894, p.72.

[5] Swami Nikhileswarananda (1964). Vivekananda - A Biography, Advaita Ashram, Kolkata, p.19.

[6] Swami Gambhirananda (1987) Yuganayak Vivekananda, Udbodhan Karyalaya, Calcutta Part 1, pp. 63-64. [In Bengali].

[7] Swami Nikhileswarananda (1964). Vivekananda - A Biography, Advaita Ashram, Kolkata, p. 83-84.

[8] Swami Nikhileswarananda (1964).Vivekananda -A Biography, Advaita Ashram, Kolkata.p.108.

[9] Swami Gambhirananda (1987) Yuganayak Vivekananda, Udbodhan Karyalaya, Calcutta Part 1, p.168-169.

[10] Ibid. pp. 187-189.

[11] Ibid. p.274.

[12] Ibid. p211-213.

[13] Ibid. p..222.

[14] Ibid. p.224.

[15] Ibid. p.164.

[16] Ibid. p.225.

[17] Ibid. p.240.

[18] Ibid. pp. 233-234.

[19] Ibid. pp.280-281.

[20] Swami Nikhileswarananda (1964).Vivekananda -A Biography, Advaita Ashram, Kolkata, p. 117.

[21] Swami Gambhirananda (1987) Yuganayak Vivekananda, Udbodhan Karyalaya, Calcutta Part 1, pp.283284.

[22] Ibid.p.220.

[23] Swami Nikhileswarananda (1964).Vivekananda -A Biography, Advaita Ashram, Kolkata, p. 92.

[24] Swami Gambhirananda (1987) Yuganayak Vivekananda, Udbodhan Karyalaya, Calcutta Part 1, p.166.

[25] Ibid. p.298-299.

[26] Marie Louis Burke (1994). Swami Vivakananda in the West, New Discoveries. The Prophetic Mission, Advaita Ashram, Kolkata, Part 1, p.p. 151-152.

[27] Ibid. pp.157-158.

[28] Ibid, Part 2, pp. 28-30.

[29] Ibid. Part 1, p.27.

[30] Ibid. Part 1, pp.81-82.

[31] Ibid. Part1, p.102.

[32] Ibid. Part1, p.137.

[33] Ibid. Part 1. p.140.

[34] Ibid. Part1, p.139.

[35] The Complete Works of Swami Vivekananda (1989), Mayavati Memorial Edition, 1989, Advaita Ashram, Calcutta.vol.4.pp. 425-427.

[36] Marie Louis Burke (1994). Swami Vivakananda in the West, New Discoveries. The Prophetic Mission, Advaita Ashram, Kolkata, Part 1, pp. 135-136.

[37] Letters of Swami Vivekananda (2012), Advaita Ashram, Kolkata, dt. $6^{\text {th }}$ May, 1895, pp. 227-228. 
[38] The Complete Works of Swami Vivekananda (1989), Mayavati Memorial Edition, 1989, Advaita Ashram, Calcutta.vol.5. p.310.

[39] Ibid. vol.6.pp.415-416

[40] Ibid. vol. 1.p.22.

[41] Marie Louis Burke (1994). Swami Vivakananda in the West, New Discoveries. The Prophetic Mission, Advaita Ashram, Kolkata, Part 1, p.152.

[42] Ibid. p.13.

[43] Swami Nikhileswarananda (1964). Vivekananda -A Biography, Advaita Ashram, Kolkata, p. 111.

[44] Letters of Swami Vivekananda (2012), Advaita Ashram, Kolkata, dt.19 ${ }^{\text {th }}$ March, 1894, pp.78-83.

[45] The Complete Works of Swami Vivekananda (1989), Mayavati Memorial Edition, 1989, Advaita Ashram, Calcutta.vol.4.pp.482-483.

[46] Ibid. vol.3. pp. 285-288.

[47] Ibid. vol.1. p. 23.

[48] Ibid. vol.3.p311.

[49] In<http://greenmesg.org/swami_vivekananda_sayings_quotes/india-on_india.php> [22.5.2016].

[50] The Complete Works of Swami Vivekananda (1989), Mayavati Memorial Edition, 1989, Advaita Ashram, Calcutta.vol.4.pp.479-480.

[51] Letters of Swami Vivekananda (2012), Advaita Ashram, Kolkata, .dt.. $2^{\text {nd }}$ Nov. 1893, pp.53-56.

[52] Ibid. dt. $7^{\text {th }}$ Aug. 1889. pp. 6-7.

[53] Ibid. $17^{\text {th }}$ Aug. pp. 7-11.

[54] The Complete Works of Swami Vivekananda (1989), Mayavati Memorial Edition, 1989, Advaita Ashram, Calcutta.vol.3.p199.

[55] Ibid. vol.8. p. 242.

[56] Ibid. vol.3. p293.

[57] Ibid. vol.3. Pp.295-299.

[58] Letters of Swami Vivekananda (2012), Advaita Ashram, Kolkata, .dt.. 1895. p.207.

[59] The Complete Works of Swami Vivekananda (1989), Mayavati Memorial Edition, 1989, Advaita Ashram, Calcutta.vol.1.p.40.

[60] Ibid. vol.1.p.53.

[61] Ibid. vol.1. p.83.

[62] Letters of Swami Vivekananda (2012), Advaita Ashram, Kolkata, .dt..8 ${ }^{\text {th }}$ Aug. 1896. pp. 299-302.

[63] The Complete Works of Swami Vivekananda (1989), Mayavati Memorial Edition, 1989, Advaita Ashram, Calcutta. vol. 1 . pp. 75-80.

[64] Ibid. vol.1. p81.

[65] Ibid. vol.1. p.82.

[66] Ibid. vol.1. Pp.83-84.

[67] Ibid. vol.1. Pp.xv-xvi.

[68] Ibid. vol.1. p.11.

[69] Ibid. vol.5. p.143.

[70] Ibid. vol.5.p.257.

[71] Ibid. vol.5.p.292.

[72] Ibid. vol.5.p.104.

[73] Ibid.vol.1.pp. 34-35.

[74] In. < ((http://www.wsj.com/articles/SB10001424052702303404704577305581227233656><The Wall street Journal $>[4.4 .2016]$.

[75] The Complete Works of Swami Vivekananda (1989), Mayavati Memorial Edition, 1989, Advaita Ashram, Calcutta. vol. 5. P.192

[76] Marie Louis Burke (1994). Swami Vivakananda in the West, New Discoveries. The Prophetic Mission, Advaita Ashram, Kolkata, Part 2. p..212.

[77] Letters of Swami Vivekananda (2012), Advaita Ashram, Kolkata, .dt. $1^{\text {st }}$ Nov. 1896.pp. 315-318.

[78] Marie Louis Burke (1994). Swami Vivakananda in the West, New Discoveries. The Prophetic Mission, Advaita Ashram, Kolkata, Part 1. p. 35. 
[79] The Complete Works of Swami Vivekananda (1989), Mayavati Memorial Edition, 1989, Advaita Ashram, Calcutta. Vol. 3.p.300-301.

[80] In. <http://jabdakhata.blogspot.in/2012/06/europe-and-its-struggles-5.html> [17 ${ }^{\text {th }}$ Oct. 2016]

\section{AUTHORS' BIOGRAPHY}

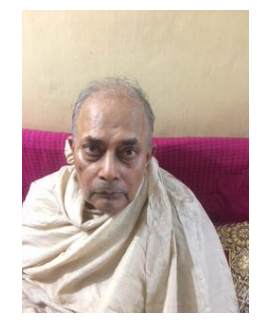

Dr Sudhish Chandra Banerjee has taken up studies on Ramakrishna-Vivekananda literature for the last few decades, post retirement as Deputy Director from a CSIR Institute at Dhanbad, and is publishing his findings on the same in various English \& Bengal Journals, as a free lance writer intending to share his thoughts with others.

The author a PhD from the Calcutta University, published two reference books on his specialization, Mine Fires, published by AA Balkema, the Netherlands and Oxford IBH pub. Co, India, simultaneously, during his working period at the CSIR Inst. before retirement $\mathrm{He}$ had around 50 research papers published in various national and international journals of repute and also 2 patents to his credit on his specialization.

Citation: Sudhish Chandra Banerjee. "Swami Vivekananda -The Thinker." International Journal of Humanities Social Sciences and Education (IJHSSE), vol 5, no. 3, 2018, pp. 1-14. doi: http://dx.doi.org/10. 20 431/2349-0381.0503001.

Copyright: (C) 2018 Authors. This is an open-access article distributed under the terms of the Creative Commons Attribution License, which permits unrestricted use, distribution, and reproduction in any medium, provided the original author and source are credited. 